\title{
Searching for Paradise in the Florida Everglades ${ }^{1}$
}

\author{
Laura A. Ogden \\ Department of Sociology/Anthropology, Florida International University
}

\begin{abstract}
This article explores the process by which the cultural history of Royal Palm Hammock, the most visited site within Everglades National Park, Florida, informs the landscape's natural history. To understand this process, I analyze the scientific literature, including naturalists' fieldwork reports, surveys, fieldnotes and other archival material spanning the late 1800 s to the mid-1930s, as well as ethnographic interviews conducted with local Everglades hunters who depended upon this landscape during the latter part of this era. As I demonstrate, local people, serving as guides and informants, critically contributed to the production of ecological knowledge about Royal Palm Hammock, though the evidence of these contributions has been distorted by the natural history literature's negative stereotypes of local landscape practices.
\end{abstract}

Keywords: Florida Everglades $•$ landscape $・$ natural history

\section{Introduction}

7 here are parts of the world that become recognized, valued, known, or 'famous', for want of a better word, based on their perceived ecological significance. These landscapes go by many names, 'hotspots' of biodiversity, habitats for endangered species, or even buffer zones, a term given to lands that serve as barriers between critical ecological habitats, such as watersheds, and adjacent development. ${ }^{2}$ Some landscapes, such as the one I am writing about here, gain mythical status for the role they have played within the field of natural history. These are geographies where ecological discoveries occurred or where fieldwork and scholarship led to larger disciplinary shifts in ecological theory or method. For instance, Wisconsin's sand counties are inextricably linked to Aldo Leopold's approach to wildlife conservation and environmental ethics. ${ }^{3}$ Of course, many such landscapes do not acquire the national, and even international, reputation of Leopold's sand counties. Instead their resonance is limited to scholars specializing in the natural history and ecology of specific regions. The Royal Palm Hammock, now within Everglades National Park, is one such locale. This article offers an account of the Royal Palm Hammock's rise to fame, and more particularly, I detail the complex history of that ascension. In doing so I demonstrate how localized spatial experiences inform processes of scientific knowledge construction.

Thousands upon thousands of tree islands punctuate the vast open marshes and prairies of southern Florida's Everglades. These tree islands are classified by the dominant types of vegetation found on them, generally either wetland species or tropical hardwoods. While wetland tree islands are found throughout the southeastern United States (the cypress swamps of the 
Okeefenokee, for example) tropical hardwood islands, called hammocks, are found exclusively in the southern Everglades (from about Miami southward - see Figure 1). The term 'hammock' has an unclear origin, perhaps originating in the Seminole word for 'home,' although the Spanish hamaca, from the Arawakan indigenous word for 'fish nets' dates to the mid-16th century, and 'hummock,' also dating from the mid-16th century, is a nautical term used to describe a small hill along a seacoast. Regardless of etymology, hammocks as habitat are unique to southern Florida, and the Royal Palm Hammock is, by far, the most famous hammock in the Everglades. ${ }^{4}$

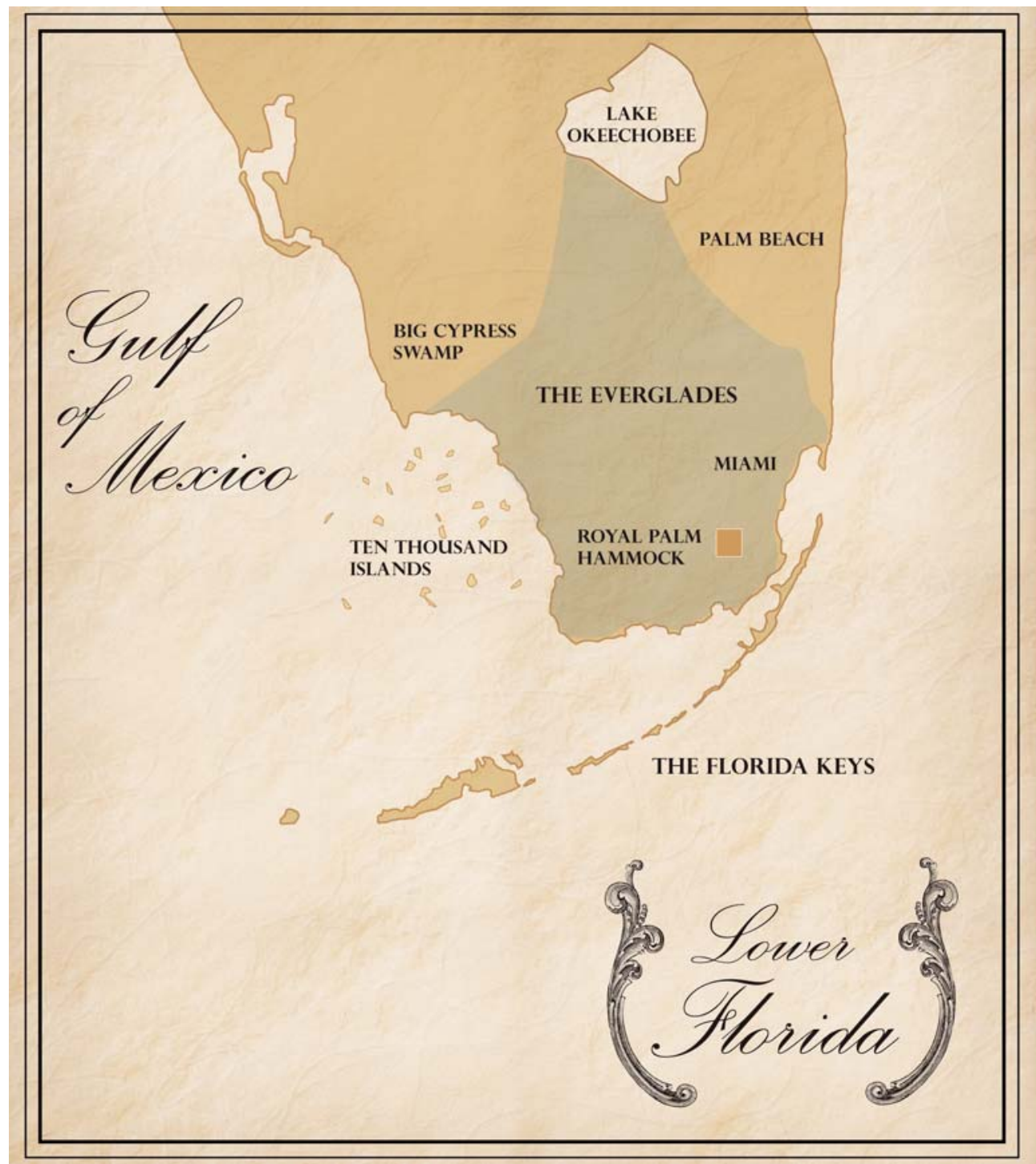

FIGURE 1 Location of Royal Palm Hammock in the Florida Everglades. 
Today, Royal Palm, which is about a mile long and a half mile in width, is the most-visited site within Everglades National Park. The 'Gumbo Limbo Trail' provides access to Royal Palm's understory. As you enter the hammock, Florida's bright heat abruptly gives way, as if you had walked into a darkened, damp closet. Immediately there is a sense of closeness, as the vegetation is dense and disorderly and the air is heavy with that musty richness particular to the tropics. The trees within Everglades' hammocks are the same species found throughout the West Indian region of the American tropics, including cabbage palms, wild tamarind, West Indian mahogany, pigeon plum, lancewood, poisonwood, wild coffee, white stoppers, and the gumbo limbo, also called the 'tourist tree,' for its red-peeling bark. Particular hammocks, including Royal Palm, are famed for their abundant bromeliads, delicate and rare orchids, and fanciful banded tree snails - making them targets for collectors of all kinds. ${ }^{5}$

To understand how Royal Palm acquired its status as a landscape of ecological significance - so significant in fact that it became the cornerstone of efforts to create a national park - I have analyzed the accounts of fieldwork that established and detailed the site's importance to the broader scientific community. This literature, spanning from the late $1800 \mathrm{~s}$ through the mid-1930s, includes scientific reports, many of which were supported by the Smithsonian and other critical research institutions of the era, letters, fieldnotes and photographs collected in archives, bibliographies of key naturalists, newspaper articles, and other published accounts of fieldwork in the Everglades. Though I have analyzed the research of numerous naturalists, the key figures discussed in this article include: John Kunkle Small, botanist and curator for the New York Botanical Garden; Charles Torrey Simpson, a conchologist locally considered the 'John Muir' of the Everglades; and Hugh Willoughby, a gentleman explorer and surveyor who was the first person to publish an account of crossing the Everglades from west to east. At the turn of the last century, this literature, particularly the work of Small and Simpson, was critical to efforts to protect and conserve Royal Palm. ${ }^{6}$ In addition, these early surveys and accounts of Royal Palm's biota continue to be important to biophysical scientists examining ecological change in the Everglades.

My analysis differs substantially from other uses of this material, as here I re-evaluate this literature to gain insight into the mechanics and cultural history of the scientific process itself, what Philip Crang has called the cultural geographies of knowledge. ${ }^{7}$ Over the last several decades cultural geographers and anthropologists have offered several approaches to theorizing the often hidden humanity of landscapes. Much of this work has focused on the ways in which naturalized environments reverberate with cultural significance, acting as repositories of cultural memory, false memories, mythology, social identity and as sites of production and reproduction. ${ }^{8}$ In a similar sense, other scholarship has interrogated the intersections of global conservation discourses, ecological claims and proprietorships, and the impact of these processes on local populations and livelihoods. ${ }^{9}$ In general, what these approaches share is an attention to the local, or localized, embodied, experience of landscape as well as a concern for how local landscape practices intersect with various constellations of power. ${ }^{10}$ In doing so, this scholarship has focused attention on the social constructions and cultural relativism of spatial experiences. Sheila Jasanoff, and others within science and technology studies, have argued for an understanding of science that 'embeds and is embedded' in the social world, rather than as a form of disembodied knowledge standing outside institutional, political and historical contexts. ${ }^{11}$ In this article, I build upon both of these literatures to examine how localized spatial 
experiences are embedded in the production of scientific knowledge about Royal Palm. Ultimately this articulation results in Royal Palm, and by extension the greater Everglades, being valued primarily for its ecological significance.

In the official national park literature that discusses the significance of Royal Palm, scant attention is given to any human history of the hammock, instead emphasizing the site's ecological worth and rarity. ${ }^{12}$ Though the visitor's experience of Royal Palm excludes indications of the site's human life, Royal Palm was once an important landscape for local peoples engaged in a variety of productive and reproductive activities. This finding will come as no surprise to readers familiar with the literature documenting the dispossession of peoples from national parks and protected areas. Roderick Neumann refers to the particular vision of nature that presupposed and supported these dispossessions as the 'national park ideal,' a Euro-American aesthetics of edenic, uninhabited wilderness. Similarly, Mark Spence's work has shown how the national park ideal relies upon an 'atemporal natural history' that effectively erases the human history of landscapes, such as those that would become Yosemite, Glacier, and Yellowstone national parks. ${ }^{13}$

As this literature details, the history of the national park ideal in the US is both simultaneous and contingent upon the encroachment of white settlers on traditional indigenous lands, as well as the genocides that made these dispossessions possible. The Everglades is no exception to this colonialist history. White settlement in southern Florida was only feasible after decades of war with the Seminole. To escape Andrew Jackson's brutal campaign of removal, the Seminoles sought refuge and independence within ever more remote areas of the southern Everglades. By the Second Seminole War (1835-1842), Seminoles were certainly living in and around Royal Palm. For instance, one of the most famous incidents of this war occurred only a few miles from Royal Palm, when Col. Harney, along with 90 men in 16 canoes, tracked down and killed the Seminole Chief Chekika at his backcountry camp. ${ }^{14}$ A few years after the war, Jack Jackson, who surveyed the southern Everglades in 1848, camped three miles from Royal Palm and referred to this region as the 'Indian Hunting Grounds', suggesting that Seminole were still living in the area at that time. ${ }^{15}$ Understanding this historical legacy and the ongoing colonialist rhetorics which frame contemporary relations and disputes over boundaries and usage between Everglades indigenous peoples and the national park is of critical importance and has yet to be written.

The time period I examine here is one in which white rural and Seminole peoples were engaged in similar hunting and trade practices, in many cases using the same landscapes for these activities, including Royal Palm Hammock. While this article explores the intersections of these histories at Royal Palm, and their distinct roles in the co-production of ecological knowledge about the site, I pay particular attention to the mechanisms that disfranchised rural white people from the landscape, a community fairly marginalized from the emerging metropolis of Miami to the north. As I discuss later in this section, naturalists constructed indigenous and rural white relationships to landscapes in starkly different terms. This article focuses on the particular conceptual space white gladespeople were assigned in the formation of Royal Palm's scientific value.

White settlers moved into the southern Everglades, living on coastal islands and on inland hammocks, after the Civil War, many fleeing the uncertainties of the post-Reconstruction South, claiming squatters' rights to unoccupied lands. My own ethnographic research has sought to 
understand how Euro-American alligator hunters experience the Everglades in ways that both complement and confound ecological narratives of place. ${ }^{16}$ For this research, I have conducted interviews with alligator hunters throughout southern Florida, in communities around Lake Okeechobee, the Corkscrew Swamp, and the southern Everglades. This research with alligator hunters, many of whom are now in their 80's and 90's, reveals an Everglades landscape where the boundaries between the animal and human worlds are blurred. It is a landscape entangled with local mythologies, production and subsistence struggles, and place-based identities. In the course of this research I was surprised at the number of gladespeople who had served as guides for visiting naturalists and national park scientists. The parents and grandparents of the people I have interviewed did not leave written accounts of their experiences in the Everglades. To gain some insight into this earlier period, I began reading the only available literature of that time, which is the early natural history, hoping to gain a glimpse of glades life through the eyes of visiting scientists. Their fieldnotes and reports are ambiguous texts at best and a narrative form that borrows heavily from the era's adventure travel writing. Both genres offer similar constructions of locals: careless rubes, alcoholics, equally infantile and dangerous, with 'local color' serving as a mechanism to claim authority over landscapes that are both inhabited and strangely beyond the pale of civilization. Here I piece together the spare clues of local collaboration in science-making at Royal Palm found in these naturalists' accounts, while at the same time using oral histories of the hammock to reframe and problematize their narratives. Doing so offers evidence of how Royal Palm's natural history, as a specific way of seeing the landscape, articulates with the site's human history.

Science is often portrayed as a sort of handmaiden to state conservation movements, as a mechanism to justify the control/and or removal of peoples from lands deemed environmentally sensitive. Yet, as Bruce Braun has demonstrated, scientific discourses are not only instrumental to the dispossession of locals from landscapes, they constitute nature and culture as knowable in particular kinds of ways. To illustrate his point, Braun analyzed the fieldwork of George Mercer Dawson, who conducted fieldwork for the US Geological Survey during the 1870s in British Columbia. In his field notes and reports, Dawson meticulously detailed both the Haida culture and the landscapes he encountered, yet his narratives contain striking bifurcations treating Native culture and the landscape as if they were unrelated categories of the world. Braun convincingly demonstrated that this demarcation abstracts Native peoples from the lived experience of their worlds. The fieldwork of Dawson and others did not ignore Native presence, instead these landscape epistemologies made legible people and nature as unrelated orders of knowledge. Braun argued that contemporary land management approaches which treat Native peoples as merely another 'stakeholder' are shaped by these earlier ways of seeing the world. ${ }^{17}$

Yet at the same time, as this case study demonstrates, naturalists treated indigenous peoples as somehow within the same romanticized conceptual space as landscapes they considered wilderness. Natural history surveys, as did natural history museums, often included enumeration of indigenous peoples and their culture, typically as if they were another notable curiosity of the landscape. ${ }^{18}$ For instance, W.E. Safford, an economic botanist with the US Department of Agriculture, conducted a survey of Royal Palm during September of 1917. His comprehensive study covered 'all branches of natural history', and included chapters detailing the hammock's trees, epiphytes, mollusks, spiders, insects, fishes, reptiles, birds, and finally, aboriginal Indians and 
their successors, the Seminole. This latter section catalogues the 'fine physique' and culture of the Tequesta and Calusa peoples, information primarily derived from Spanish colonial accounts, as well as the use of native plants by the contemporary indigenous peoples.

Uneasily, and certainly problematically, naturalists considered indigenous peoples as somehow of the landscape, spatially naturalized within particular biota and geomorphology - this metonymic association arising, no doubt, from earlier debates concerning the singular or multiple origins of racial types. On the other hand, naturalists' constructions of nonindigenous peoples were substantially different. Not only were Euro-American inhabitants of wilderness abstracted from nature, they were also constituted as out of place. This was certainly the case at Royal Palm, which was not only a landscape devoid of humanity, but a landscape naturalists considered under siege by rural whites.

The central argument of this article is that becoming ecologically famous, and thus worthy of protection, required the transformation of Royal Palm Hammock into a 'smooth object,' Bruno Latour's term for ontologies devoid of their inherent material and ideological conflicts, incongruities and biosocial entanglements. ${ }^{19}$ Smoothing out Royal Palm required the 'generification' of the site's ecology and its peoples into intelligible, stable and generalizable categories of the world. ${ }^{20}$ For naturalists, Royal Palm came to represent a singular example of the tropics within the continental United States. Its ecological value lay in its exotic and pristine tropicality, a generalized taxon that was considered particularly worthy of investigation and protection. Similarly, naturalists portrayed the rural whites living in and relying upon this tropical exemplar as nonendemic invaders. This form of generification required a monocular vision that ignored the diversities of the hammock's social nature. First, naturalists simply did not see, or did not acknowledge, the intimate connections rural whites had to the site, including ample evidence of long term and multiple strategies of production and reproduction. Second, what naturalists did see corresponded to their sense that all white presence within the Everglades was equally detrimental, making no distinction between the people who had been living within the Everglades for a century and the mass of recent arrivals settling and transforming southern Florida at that time. Third, although both rural white hunters and Seminole people were fundamental to the fieldwork which established Royal Palm's scientific worth - literature which was directly used to justify the hammock's protection as a state park and later a national park - naturalists discounted local ways of knowing the landscape by portraying these epistemologies as rudimentary and intuitive.

What follows is an account of the complex material and discursive relationships between naturalists, white local peoples, and the construction of Royal Palm's scientific significance, focusing on the late 19th and early 20th centuries. I start by examining one of the first visits to the hammock by a non-local, Hugh Willoughby, who conducted a survey in the southern Everglades in 1897. In the next section, the article examines the history of fieldwork at Royal Palm and explores how the quest to discover unique and rare biota determined the specific ways in which the hammock became ecologically significant to the naturalist community. In All creatures: naturalists, collectors, and biodiversity, 1850-1950, Robert Kohler provides a compelling study of the transformations in American cultural values and infrastructure that prefigured and supported natural history research at the beginning of the last century. ${ }^{21}$ Due to the scale of Kohler's project, his portrayal of local non-specialists in natural history fieldwork stems primarily from naturalists' accounts. By incorporating ethnography and other sources, 
I am able to provide a more nuanced understanding of the social relations of scientific production. As a counterpoint to naturalists' representations of Royal Palm's natural history, the third section details the hammock's human life, which is considerably circumscribed in the naturalists' accounts. In the final section, I draw on Bruno Latour's concept of 'smoothing out' to describe the production of natural history discourses. This smoothing out, I argue, entails the generification of the site's social nature, a representation that ultimately shapes contemporary understandings of the Everglades' human history as singularly threatening.

\section{Discovering Paradise}

Southern Florida's naturalist community first became aware of Royal Palm in the late 19th century, though it was not until the early years of the next century that these scholars began to publish detailed descriptions and surveys of the hammock's flora, fauna, and geomorphology. One of the greatest obstacles to conducting fieldwork in the southern Everglades was the landscape's perceived inaccessibility and related problems of navigating an 'unmapped' landscape. ${ }^{22}$ Rendering the Everglades legible for field research required surveying the landscape, of which several efforts were undertaken between the late 19th century and the early decades of the 20th century. Most notably, Hugh deLaussett Willoughby, of New Port, Rhode Island, conducted one of the earliest of these surveying efforts. His account, Across the Everglades: a canoe journey of exploration, initially published in 1898, offers the first record of a westward passage across the Everglades, and includes a visit to Royal Palm. ${ }^{23}$ Willoughby, as befitting the narrative style of the era, described his Everglades exploration in terms that highlight the landscape's exoticism and hitherto unknown qualities, geographically situated within the poetics of colonial encounters:

It may seem strange, in our days of Arctic and African exploration, for the general public to learn that in our very midst... we have a tract of land one hundred and thirty miles long and seventy miles wide that is as much unknown to the white man as the heart of Africa. ${ }^{24}$

As Willoughby's goal was to establish an accurate surveying transect across this unknown landscape, he prepared for his trip with rigor, spending a year attending to the details of navigational equipment, boat rigging, and appropriate clothing.

His serendipitous encounter with a local hunter named Ed Brewer, whom he 'accidentally met' while in the then frontier town of Miami, proved fortuitous. Here and there, other narratives briefly mentioned Brewer, and these accounts coalesce to form an incomplete sketch of the man's biography. Willoughby's descriptions of Brewer seem ethnological in tone, and are worth repeating:

He was a man of medium height, heavily built without being fat, black hair, black eyes, inured to hardship, and able to make himself comfortable in his long tramps, with a canoe, a tin pot, a blanket, a deer-skin, a mosquitobar, and a rifle, with perhaps a plug or two of tobacco as a luxury. ${ }^{25}$

According to Willoughby, Brewer was born in Virginia, although he had lived in the southern Everglades for many years, supporting himself as a hunter and trapper. Local gossip suggested the man's character was questionable, and in fact Willoughby's friends warned against hiring him. ${ }^{26}$ 
Several years later another local guide told A.W. Dimock, a travel and adventure writer, that a shoot-out with a disreputable neighbor forced Brewer to relocate from the Ten Thousand Islands, on the Everglades's west coast, to Miami. ${ }^{27}$ C.S. 'Ted' Smallwood, in his memoir of pioneering life on Chokoloskee Island during the late 1800s, mentioned in passing that Brewer was known for trading with area Seminoles at their backcountry camps. Smallwood said that Brewer would leave with a canoe loaded down with liquor and calico, and return from the glades with money and skins. ${ }^{28} \mathrm{He}$ was also a man that enjoyed playing the fiddle for small gatherings. ${ }^{29}$ Whatever Brewer's character, his knowledge of the Everglades backcountry and expertise seemed to have been locally well-established. For instance, six months prior to guiding Willoughby, Brewer led a three-day hunting and exploration trip into the Everglades for a party that included a local judge, a point which would suggest that whatever Brewer's reputation his distinction as a guide outweighed any concerns for personal safety. ${ }^{30}$

Willoughby had never camped in the Everglades before, so for over a month Brewer tutored Willoughby in what could and could not be eaten, hunted and fished for their food, located dry sites for making camp, and hauled an onerous amount of surveying equipment and other supplies across the Everglades in a canvas-covered canoe. Willoughby appreciated Brewer's attentions, as the following passage suggests:

I always found him brave and industrious, constantly denying himself, deceiving me as to his appetite when our supplies ran low that I might be more comfortable, and many a night did he stay up an extra hour while I was finishing my notes and plotting work, that he might tuck me in my cheese cloth from the outside. ${ }^{31}$

While Brewer's role of caretaker in this journey is clear and appreciated in Willoughby's account, the reader's sense of Brewer's expertise as a guide remains more elusive. Willoughby's endless narrative of sexton readings, surveying stations, longitudinal and latitudinal points convey and establish his techno-expertise, certainly contributing to the account's ongoing legitimacy. Yet evidence from other sources suggests that Brewer also had considerable knowledge of the Everglades' famously difficult terrain, reportedly spending periods of up to six months in the backcountry at a time. It also seems that he had traveled on at least half of Willoughby's route previously. For instance, Brewer claimed squatters' rights on an island full of towering palms at the southern end of Long Key, a series of inland islands that served as an important designation and reference point throughout Willoughby's journey. This island later became known as the Royal Palm Hammock.

We can only guess at what each man learned from the other on their trip across the Everglades. Judging from the subsequent accounts and literature on the historic Everglades, Brewer's claims to Royal Palm Hammock and his considerable knowledge of the landscape do not become a part of the concordance contributing to the Royal Palm Hammock's fame. Aside from his explorations in the Everglades, Willoughby is remembered as a famous aviator, colleague and friend to other famous aviators, including Orville Wright, and founder of the Rhode Island Naval Reserve. No doubt his social connections also contributed to his account's popularity. Willoughby's book was certainly successful, reprinted in several editions, and was reviewed in prestigious journals, including The geographical journal, of the Royal Geographical Society, and the Journal of the American geographical society of New York. While Willoughby's exploration brought attention to the Everglades landscape, including the attention of naturalists, 
Royal Palm's history of fieldwork, as I discuss in the next section, reveals how the quest to discover unique and rare biota determined the specific ways in which the hammock became ecologically valued.

\section{The landscape's mysterious magic}

Royal Palm's rarity lay in its towering stand of royal palm trees, as the name suggests. Yet while these palms brought the hammock to the naturalist community's immediate attention, the hammock's real (and exotic) appeal lay in its status as a rare exemplar of the 'tropics' within the continental United States. Vladimir Nabokov, when discussing the production of scientific knowledge, said that some landscapes have a kind of 'mysterious magic' that propels naturalists to discover new species and the unknown qualities of nature. ${ }^{32}$ Nabokov, with his well-known obsession with butterfly taxonomy and collecting, would have found a kindred spirit in Charles Torrey Simpson, the Everglades' most famous early naturalist. Simpson, a conchologist by specialization, reportedly could identify 10,000 shells by sight and Latin nomenclature. ${ }^{33}$ In terms similar to Nabokov, Simpson described his own deep connection to the process of fieldwork:

I do not want to investigate nature as though I were solving a problem in mathematics....In my attempts to unravel its mysteries I have a sense of reverence and devotion, I feel as though I were on enchanted ground. And whenever any of its mysteries are revealed to me I have a feeling of elation... just as though the birds or the trees had told me their secrets and I had understood their language... ${ }^{34}$

Royal Palm's mysterious magic offered naturalists a way of encountering and seeing the landscape through the prism of its unknown qualities and rarities. The practice of fieldwork became the method for translating the landscape's mysterious magic into disciplined knowledge.

John Kunkel Small, pre-eminent botanist and curator for the New York Botanical Garden, in his article 'Royal Palm Hammock' offered a history of fieldwork at Royal Palm, and reported on two 'independent' discoveries of the hammock that occurred in the late 1800 's. ${ }^{35}$ Both of these discoveries were facilitated by Seminole people who were living and hunting in the area, a point suggesting that whatever rights Ed Brewer had to the island, other people were already occupying it, at least on and off, prior to his claim. In the first instance, Kirk Munroe, an early settler, author, and advocate for the Seminole, recalled being guided to an Indian camp in February of 1882 that was established 'on the edge of a low hammock,' where a number of royal palms grew in February of $1882 .{ }^{36}$ This visit to the hammock took place during a four-month canoe trip Munroe took along Florida's western coast. Two Seminole men asked Munroe to follow them back to their camp, a distance of 25 or 30 miles away, to aid an ill child. Tragically, by the time Munroe's party reached the camp, the child had died. Though Munroe only spent one evening at the Seminole camp, he was struck by the presence of a magnificent stand of royal palms there. Munroe took particular note of the trees as he had not encountered them elsewhere in the Everglades, though he recognized the species, having seen it previously while traveling in Panama. Years later, when writing about Small, Munroe was convinced that this Seminole camp was the 'Royal Palm Hammock,' having sighted the hammock again on another trip in 1900. 


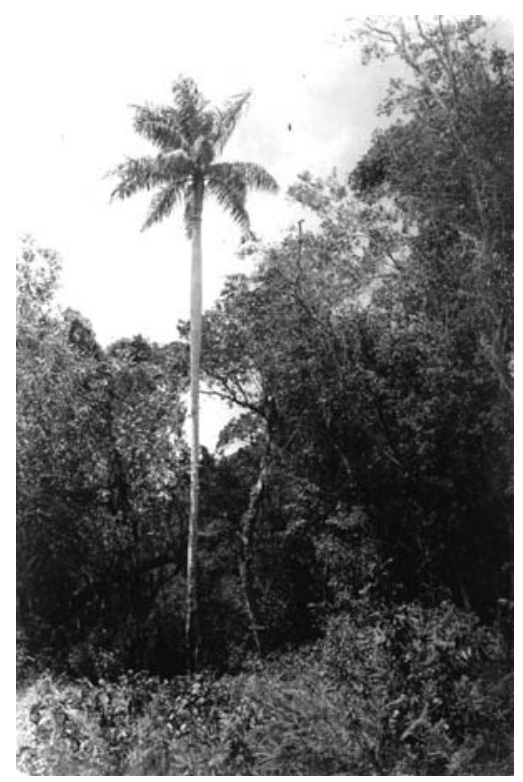

FIGURE 2 Royal Palm, at Royal Palm Hammock. (photograph by John Kunkel Small, 1918, courtesy State Archives of Florida.)

The second 'discovery' of the hammock, as reported by Small, provides a crucial link in the history of fieldwork at the site. In 1893, Francis M. and John J. Soar, nurserymen and amateur botanists who lived in the Little River settlement in what is now northern Miami, were told about a 'large island, with many tall palms growing on it' by Seminole camping near their home. ${ }^{37}$ For their nursery business the Soars grew citrus for northern markets, later specializing in ornamentals propagated from native plants. Many of these plants were collected during botanical explorations with visiting naturalists. ${ }^{38}$ To reach the hammock, the Soar brothers sailed southward along the eastern coast of Florida, up the Black Point Creek, until it ended where the 'pinelands meet the everglade prairie.' The brothers then walked about 20 miles along the prairie before sighting the aforementioned tall palms, to reach the hammock they waded six miles across the slough that borders the island. ${ }^{39}$

The presence of these mysterious and rare towering palms certainly impressed John Soar, as he later undertook this fairly difficult journey on at least two other occasions while guiding naturalists to the site. When naturalists were first conducting fieldwork at Royal Palm Hammock, there were approximately 100 of these palms at the site, rising high above the rest of the hammock's vegetation. It is clear that the royal palms granted the hammock its initial distinction and struck even the most seasoned naturalist with considerable awe. Charles Torrey Simpson, after describing the hammock's many properties said, 'But the glory, the matchless triumph of the great forest is the royal palms.' ${ }^{40}$ In their words, the palms lent the hammock nobility and charm, making the site the 'most romantic hammock in the southern tip of the state. ${ }^{41}$ The palms were like 'arboreal monuments,' signaling the hammock's botanical importance. $^{42}$ The royal palms, most importantly, were what made the hammock unique. ${ }^{43}$ 


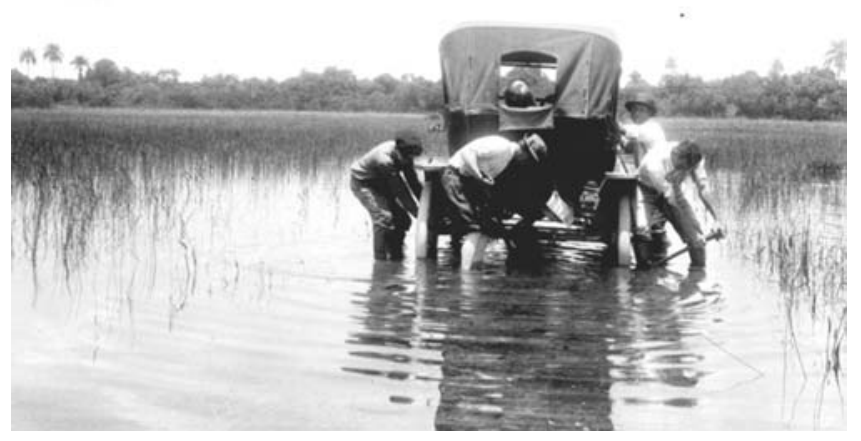

FIGURE 3 John Soar's truck stuck in the mud near Royal Palm Hammock. (Photograph by John Kunkel Small, 1915, courtesy State Archives of Florida.)

Today, within the discourse of contemporary ecological claims making, the presence of a single rare species, for instance the infamous spotted owl, justifies the ecological territorialization of landscapes. In the case of Royal Palm, the literature suggests that these naturalists felt the need to establish the landscape's ecological worth beyond the mere presence of these exceptional trees. To authenticate the Royal Palm's overall ecological importance required repeated surveys of the hammock, which taken together, form a genealogy of field research, and importantly, a replicable record. The Soar brothers must have told Small about Royal Palm, for Small, who knew the Soars, appears to be the first institutionally-supported scientist to conduct research at the site, which he did in 1903. ${ }^{44}$ A few months later, John Soar, who was Charles Torrey Simpson's neighbor, guided Simpson and Alvah Augustus Eaton, a fern specialist, to the hammock. ${ }^{45}$ On this trip, the men drove the 'preposterous' roads from Miami into the glades, stopped at a camp once used by surveyors, then trudged on foot the last three miles to the hammock. Simpson described the walk through the rocky glades as consisting 'mostly in slipping down and getting up again,' oftentimes while wading through water up to their armpits. During the trip, Eaton became badly shaken after stepping on the tail of an alligator, mistakenly thinking it was a log, and John Soar became terribly ill, a result, Simpson suggested, from the nauseating odor of a rattlesnake the party skinned for a specimen. ${ }^{46}$

In the years between the Soars' first visit, in 1893, and the establishment of the Royal Palm State Park, in 1916, at least 20 separate documented research expeditions were undertaken. The institutional affiliations and academic credentials of the scientists who conducted research at Royal Palm indicate the wide-spread interest and importance of the location to the naturalist community. For instance, in 1904, Nathan Lord Britton, Director-in-Chief of the New York Botanical Garden visited the hammock, as did Roland Harper, one of ecology's early pioneers, though he was still a graduate student at Columbia University at the time, and Peter Henry Rolfs, then Plant Pathologist in charge of the USDA's Sub-tropical Laboratory in Miami. ${ }^{47}$ A few years later, in 1908, Ernst Bessey, well-regarded botanist and son of Charles Edwin Bessey, considered the father of modern botany, and the plant pathologist G.L. Fawcett conducted fieldwork at the hammock. John C. Gifford, one of America's first professional foresters, and a strong voice for swampland reclamation and protection of 
Royal Palm, visited the hammock in $1916 .{ }^{48}$ The following year, W.E. Safford, of the US Department of Agriculture, produced one of the most comprehensive surveys of Royal Palm's biota and natural history. During this time period, Small returned to Royal Palm on at least 15 occasions, and Simpson also made repeated trips to the hammock. By 1916, researchers documented 241 kinds of plants, which included 162 native species. Safford not only exhaustively characterized the entirety of the hammock's natural history, but deposited representative samples into collections at the Smithsonian Institute, the United States National Museum, the Bureau of Entomology, and at the Bureau of Biological Survey. ${ }^{49}$ Arthur Howell, ornithologist for the Bureau of Biological Survey and author of the seminal Florida bird life, produced a list of 128 species of birds spotted in or around the hammock, though he considered the hammock's birdlife 'surprisingly meager'. ${ }^{50} \mathrm{By}$ any measure, this is a considerable record of fieldwork, particularly since the location spans only about 400 acres.

Importantly, this baseline information allowed these researchers to situate the hammock's characteristics and value in relation to other landscapes in the known world. The consensus was that the hammock contained both specimens 'new to science' and represented a habitat 'not before known to occur naturally in the United States'. ${ }^{51}$ That unknown habitat was the tropics. As David Arnold has argued, the determination of tropicality becomes a way of defining landscapes as both 'alien and distinctive' from European temperate climates, making them a kind of privileged locale for experiencing and studying nature. ${ }^{52}$ The sense of wonder at discovering a tropical wilderness within the continental United States is a trope repeated throughout these accounts of early fieldwork. Safford described Royal Palm as 'almost unique from a biological point of view, presenting as it does a remarkable example of subtropical jungle within the limits of the United States in which primeval conditions of animals and plant life remained unchanged by man'. ${ }^{53}$

In effect, these naturalists treated the landscape as if it were a geographic extension of the tropics, comparing the location, at various times, to the West Indies, western Cuba, the Bahamas, Jamaica and Puerto Rico, among other popular sites for tropical fieldwork. In doing

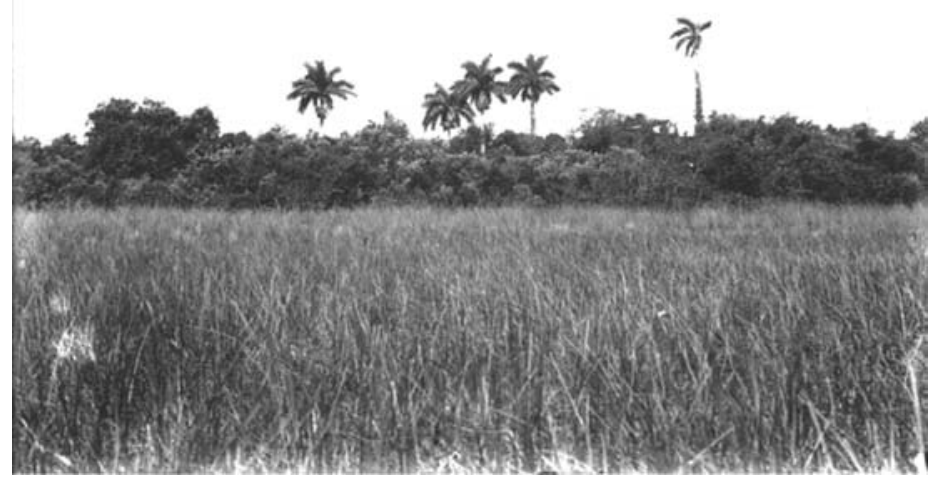

FIGURE 4 Royal Palms along the eastern side of Royal Palm Hammock, 1916. (Photograph by John Kunkel Small, courtesy State Archives of Florida.) 
so, their narratives incorporated their fieldwork into a broader disciplinary tradition of tropical natural history dating back to Alexander von Humbolt's travels in South and Central America at the turn of the 19th century. ${ }^{54}$ During these early years of research at Royal Palm, the lure of the tropics certainly had not waned. For instance, in 1902, just one year before Small conducted his first survey of the hammock for the New York Botanical Garden, his supervisor, Nathan Lord Britton, began his 30-year fieldwork on the tropical flora of Puerto Rico. Discursively reterritorializing this southern Florida landscape into the tropics invested the hammock with exotic allure, certainly increasing the hammock's visibility as a site for fieldwork, continued institutional support, and, eventually, protection. Moreover, by ascribing tropicality to the hammock naturalists were able to increase the site's legibility, fitting it within known categories of the world while at the same time arguing for its uniqueness.

This era of fieldwork at Royal Palm corresponds to what Robert Kohler has described as the 'survey' period of American naturalist research in his recent All creatures: naturalists, collectors, and biodiversity, 1850-1950. In Kohler's thorough analysis he offers critically important insights into the broad transformations in American society that shaped the culture and practice of natural history survey work at the turn of the last century. One of Kohler's central arguments is that during this time period changes in American social values and practices toward wilderness, transportation networks, and mixed gradients of settled and undisturbed land uses brought many Americans into closer contact with 'wilderness' landscapes. In effect, wilderness was essentially now in peoples' backyards.

This proximity resulted in new forms of residential knowledge about these inner frontiers,' Kohler's term for the America's intermingled landscapes of 'densely inhabited and wild areas' of the era. By examining naturalists' reports, fieldnotes, and other archival material, Kohler demonstrated the critical importance of residential knowledge to the era's natural history survey work. Kohler uses the term residential knowledge to distinguish between particularistic and global forms of knowledge, with residential knowledge suggesting an experiential epistemology that 'comes from living in a place' which differs from the global (theoryproducing) knowledge scientists practice. ${ }^{55}$ Institutional and financial constraints limited the time field scientists had for their research. Residential knowledge, therefore, acted as catalyst to the naturalists' knowledge of the inner frontier's specificities. In particular, Kohler revealed the close connections and indebtedness field scientists had to 'amateur' naturalists, such as members of bird-watching clubs. The practice of professional fieldwork, with its claims to scientific authority, transformed the amateur's residential knowledge into globalized, as Kohler described it, 'cosmopolitan' scientific knowledge. On the other hand, professional naturalists found the residential knowledge of other locals, such as hunters or commercial harvesters, less reliable and often the assistance of these locals downright counterproductive. Kohler's interrogation of field scientists' accounts presents a portrait of these locals as ambiguous at best, at worst as untrustworthy drunks, inept to the demands of proper specimen preparation, and even as folks apt to steal the valuable specimens they were hired to collect. I have no doubt that this is the message which resonated in Kohler's sources. ${ }^{56}$

Yet due to the broad scope of his investigation, Kohler leaves unexplored the social relations of this place-based knowledge production. One wonders how amateur naturalists first came to know the landscapes of the inner frontiers. How did this residential knowledge move up the chain of ever-authoritative command? A cartography of science should attend to the 
social relations of knowledge production including the nuances of residential knowledge exchange. By focusing in on the mechanisms of knowledge production at specific places, such as Royal Palm, I am able to trace the intersections and absences that characterize the social relations of place-based knowledge. Unnamed Seminoles brought Royal Palm's attention to explorers, such as Kirk Munroe, and amateur naturalists, such as the Soar brothers, who were interested in local botany and propagating this flora for commercial purposes. The Soars then introduced the hammock to professional naturalists, such as John K. Small and Charles Torrey Simpson. Euro-American hunters, such as Ed Brewer and countless others, served as guides to the hammock and other regions of the Everglades backcountry. The published accounts resulting from these networks of relations alerted other naturalists to the site.

These networks of relations offer a clue into the process by which residential knowledge became transformed into scientific knowledge of Royal Palm. My own fieldwork with gladespeople who served as guides to visiting naturalists suggests the motivations cementing these relationships were highly variable. Some guides assisted solely for the money, and were often skeptical of naturalists' abilities to 'know' the landscape, as they did, in such a short time. Others were motivated by friendships and a sense they were contributing to important research. Some guides, particularly those working after the national park was established, used these fieldtrips to survey areas closed off to them, occasionally returning to those sites for clandestine hunting. These varied and overlapping motivations surely shaped locals' relationships with naturalists and the coproduction of knowledge, then and now. We can only surmise the motivations, and related power dynamics, that informed Royal Palm's history of fieldwork. What is clearer is that the landscape's mysterious magic, the lens for viewing Royal Palm's rarities, was decidedly monocular, leaving much of the hammock's life only partially visible, as I discuss in the next section.

\section{The social life of hammocks}

Southern Florida remained sparsely settled well into the first decades of the 1900s. Like many rural southern landscapes, such as the swamp communities in Georgia's Okeefenokee or the hard scrabble hamlets of Appalachia, economic opportunities were few and the poverty was palpable and enduring. ${ }^{57}$ As in these other communities, people living on the margins of the Everglades depended on hunting, fishing and foraging for their livelihoods. A friend in his 80 's told me in an interview that during the 1920s and '30's hunters sought out 'whatever we could sell or trade for survival,' noting that when in the Everglades they were always 'looking for something to eat or sell.' During the time naturalists were conducting fieldwork at Royal Palm, these livelihood strategies included collecting and selling orchids, alligator and crocodile eggs; hunting for plume birds, alligator, otter and raccoon; and clearing hammocks (the only high ground around) for gardens, small farms and home sites. For subsistence, hunters sought deer, turtle, and a variety of wild birds, the white ibis, or 'curlew' being a particular favorite.

Seminole and Euro-American hunters employed similar hunting techniques, sold their hides and pelts to the same buyers, bought supplies, such as ammunition, guns, sewing machines, and dry goods, at the same trading posts. ${ }^{58}$ For both Seminole and Euro-American settlers, this hunting and foraging lifestyle required spending extended periods in the Everglades, with 
hunting parties staying in the backcountry for weeks on end, walking and poling canoes or narrow skiffs across miles of open marsh and mangrove swamps. When on these backcountry trips, hunters used hammocks as camp sites. Depending on how well the hunting was in a particular area, hunters would stay at their camps for a few days to a couple of weeks. White gladespeople had their own hammock camps, which they 'claimed' and named, and at some buried canned goods (such as cooked down meat) and supplies (such as dry wood or a change of clothes) hidden until their return. As one man described these camps:

Before the park, men had camps all over this country. There must have been a hundred of these camps that we used when gator hunting. A camp could be in a hammock or just a hole hollowed out; usually it was just a piece of higher ground that had been cleared. Most of these camps were just drift camps, places where the peat had settled and formed a small mound and a hammock would get started..$^{59}$

Upon arriving at a hammock, hunters shook out some dried grass and piled it up to form a higher place to lay their gear. They fashioned mosquito netting from cheese cloth or flour sacks, called 'skeeter bars,' using whatever was handy, their rifles, axes, or blankets, to hold the bar in place while they slept. At these hammock camps, hunters prepared their hides, cleaned their guns, sharpened their knives and axes, and gathered around campfires, drinking and talking.

My interviews with former alligator hunters indicate that Seminole and white settlers continued to hunt and camp on the hammocks in and around Royal Palm well into the 1930s, even after the hammock was designated a state park in 1916. In fact, hunting and trapping activities continued up to and after the establishment of the national park in 1947, particularly in accessible areas such as Royal Palm. ${ }^{60}$ Stories abound of Prohibition-era moonshiners running whiskey stills throughout Royal Palm, taking advantage of the hammock's fresh water and slow-burning wood. During this same time period, just outside the boundaries of the hammock, fairly large-scale truck farming took place, complete with on-site vegetable packing facilities. It seems that the slough that runs along Royal Palm, conventionally called Taylor Slough, was locally referred to as 'dead-pecker slough,' a reminder of the consequences of consorting with the prostitutes that 'hung out' at the farm labor camps. Clearly local practices of production (and reproduction if the stories of prostitution are true) required an intimate knowledge of the landscape.

This social history distorts the naturalists' narrative of an undiscovered and isolated hammock. Naturalists dealt with this contradiction by constructing local landscape practices as deviant to the site's ecological integrity, repeatedly portrayed Euro-American presence at Royal Palm as being 'out of place,' and largely transgressive to nature's economy. In their descriptions of the site, and the Everglades more generally, naturalists make brief mention of the Seminole - when human life is acknowledged. Their inclusion of the Seminole in the conceptual space of the Everglades is hardly scholarly or thoughtful. Instead, the Seminole serve as a metonym for the landscape's isolation. The Seminole (nameless, stable categories of difference) belong to the landscape and help to frame and establish Royal Palm as a remote tropical Paradise awaiting discovery. For example, Small attributed the late discovery of royal palms in Florida to the fact that 'parts of the Florida peninsula [have] not been penetrated by the white man'. ${ }^{61}$ Similarly, the materials advertising Willoughby's famous journey portray the Everglades as a Seminole landscape where 'no white man had ever traveled'. ${ }^{62}$ In some 
sense, the presence of the Seminole, as a narrative trope, acts to preclude the emplacement of rural whites. While the mechanics of this landscape racialization are beyond the scope of this paper, it serves as a strategy of scientific claims making and as a means of determining who belongs and who does not.

Yet the narrative effacement of rural whites from the site's natural history was far from complete. The extent and ways naturalists' recognized this community speaks to the mechanisms of 'smoothing out,' which ultimately casts this history aside. Concern over the hammock's future is a palpable refrain throughout the early Everglades literature. For instance, Small, in an overview of his research in southern Florida during 1915, argued for the urgency of this fieldwork in the face of 'exceedingly far-reaching and conspicuous changes taking place with the southward advance of civilization in the little known' region. ${ }^{63} \mathrm{~A}$ few years later, Simpson decried the changes that had taken place in the decades since he first started his fieldwork in southern Florida saying, 'I arraign our civilization before the bar of justice for its high crimes and misdemeanors in destroying all that is useful and beautiful which nature has so bounteously given us'. ${ }^{64}$ Again and again, the threat of environmental change disrupts the objective tone of this literature. Small, in particular, warned of the need to protect the hammock from locals. Specific transgressions Small detailed include intentions to clear the hammock for a future citrus grove and the introduction of exotic species. ${ }^{65}$ Without a doubt, Royal Palm's social history does include episodes of local commodification of the landscape. For instance, in the same newspaper article that detailed Brewer's 'squatter's rights' on Royal Palm, the author mentioned that Brewer was at the time engaged (apparently unsuccessfully) in selling the hammock's towering palms. ${ }^{66}$ Still, even considering this and other similar episodes, the naturalists' accounts present only a partial vision.

Though naturalists' considered the practices of white gladespeople a threat to the ecological integrity of the site, they also depended upon local information, or residential knowledge, for the success of their fieldwork. Naturalists attended to this incongruity by constructing local landscape epistemologies as being distinctly inferior to knowledge gained through fieldwork. Small made a particular point to distinguish between the kind of knowledge held by 'hunters who penetrated the Everglades in search of the furs and skins of various native animals' and the information produced systematically through scientific exploration. ${ }^{67}$ Even Simpson, who throughout his writings articulated his respect for the people he encountered during his fieldwork, characterized local understandings as distinctly unsophisticated: "The sight and other senses of people who habitually live in the wild are much more acute than those of any one whose abode is within the pale of civilization. These jungle people live in a large degree by the use of their senses; those of the towns and cities by their wits'. ${ }^{68}$

Robert Kohler's description of the 'inner frontier' aptly characterizes the development patterns of southern Florida in the early decades of the 20th century, where 'wild and settled were unusually extensive and permeable'. ${ }^{69}$ While once southern Florida's commercial center had been Key West, over 100 miles south of the mainland, struggling settlements along the coastal ridge, such as Miami and Coconut Grove, were becoming increasingly important tourist destinations and cities in their own right. Specially charted buses and trains brought Northeastern investors into the Miami area, upon arrival they were immediately bombarded by real estate agents seeking prospective clients. ${ }^{70}$ Far-reaching advertising campaigns spurred these speculative practices, leading some investors to buy Florida swampland unseen. By 1924, 
both the price of land and number of building permits issued in Miami skyrocketed, ranking it well above other southern cities in real estate development. ${ }^{71}$ This real estate boom brought about rapid transformations of the landscape, with hundreds of acres of mangrove forests, scrubby pinelands, and inland hammocks cleared for development. The creation of southern Florida's inner frontier, and related rapid transformations in the landscape's characteristics, corresponded to this era of fieldwork at Royal Palm, and as Kohler argued, facilitated their work. For instance, the 'Ingraham Highway' was completed in 1916, linking Miami to Royal Palm. While it took several days for naturalists to reach the hammock during the first few years of survey work, with the building of the Ingraham Highway naturalists and others were able to reach Royal Palm in an afternoon.

As Karl Jacoby has shown, conservation projects have historically constructed local landscape practices as degrading to the environment. As an antidote, and in opposition, conservationist discourses privilege techno-expertise as a more rational approach to managing land and resources. ${ }^{72}$ The field history of Royal Palm suggests that conservationist projects not only called upon scientific knowledge to establish the site's worth for protection, but that field scientists embodied a conservationist ethos. Naturalists' surveys and fieldwork were used both to justify efforts to protect the site from local usages and served to construct locals as generalized threats to the hammock's ecological value.

Hunters' stories of Royal Palm circulated for years before surveying or fieldwork began at the site, with even Florida's governors, at the far reaches of the state, aware of the hammock's fame. ${ }^{73}$ Yet it was the naturalists' reports of Royal Palm's tropical rarity that brought the hammock national attention and supported protectionist movements. Not inconsequential to the construction of the hammock's natural value was the generification of the site's human occupation and history. For these naturalists, all signs of 'civilization,' to use their racially charged term, signaled a generic threat to the hammock's integrity. Naturalists perceived the abundant evidence of the hammock's social life as an extension of the processes of land transformation occurring elsewhere. While Seminole peoples, when mentioned at all, were treated as somehow naturalized to the site, white gladespeople epitomized the possibilities of encroachment and therefore were external to the hammock's history. By portraying this community as out of place, naturalists' accounts 'smooth out' the complex political economy and cultural significance of local landscape practices. It is as if the landscape's mysterious magic cast a shadow over the history of Indian removal, multicultural exchange networks, rural poverty, and related practices of production that mark Royal Palm as being both known and appreciated outside the confines of fieldwork.

\section{Conclusion: Paradise lost}

Ed Brewer named the island hammock he guided Hugh Willoughby to in 1897 'Paradise'. ${ }^{74}$ Years later, when Brewer's Paradise became the first protected area within the Everglades, it was rechristened Royal Palm State Park. ${ }^{75}$ Charles Torrey Simpson advocated keeping the name 'Paradise Key, noting that six other hammocks in the Everglades also offered substantial stands of royal palms, with a hammock on Cape Romano to the northwest containing 500 of the species. ${ }^{76}$ Simpson was troubled with the appropriate 'priority' of naming, as Cape Romano's 
hammock had held that title for many years. ${ }^{77}$ While a valid concern, the renaming of the hammock is indicative of the larger 'smoothing out' process that occurs when landscapes become valued for their ecological rarities, even when these rarities, the royal palms, were not quite so rare.

Brewer's edenic nomination ironically foreshadowed his eventual banishment from the hammock's genealogy of knowledge production and human history. Nowhere in the hammock's scholarly literature is there mention of Ed Brewer. Brewer, like countless others who assisted naturalists and surveyors throughout the Everglades, had the specialized knowledge of the Everglades backcountry that made him the natural choice to act as guide and informant. Yet the landscape's natural history embodies a tension, which continues today, which posits a distinction between expert knowledge and local practices, blurring the correlation between these two knowledge regimes.

It is as if ecological fame-making is a process that effaces all other landscape visions from our popular consciousness, turning the landscape into what Bruno Latour had called a 'smooth object'. Smooth objects, Latour explained, are materialilities containing clearly defined boundaries and essences, 'matters of fact,' belonging 'without any possible question to the world of things, a world made up of persistent, stubborn, non-mental entities defined by strict laws of causality, efficacy, profitability, and truth' ${ }^{78}$ When places become ecologically famous, belonging solely to the world of things and facts, their social natures are polished smooth, removing discordances, such as, in the case of Royal Palm, the history of access, use, racialization, and transformation of lands by peoples in conflict and accord.

To account for the incongruity of discovering an unknown landscape in the midst of a clearly lived place, naturalists' practiced a form of selective recognition. Two rhetorical strategies accomplished this positioning. First, in constructing the site as worthy of their fieldwork, in other words as an isolated tropical Paradise, naturalists' constructed certain people, the Seminole, as naturalized to the landscape, while treating other people, rural whites, as both out of place and as threats to the continued viability of the hammock's unique biota. Second, the literature repeatedly discounts the relationship between local landscape practices and place-based knowledge, constructing these forms of residential knowledge as being distinctly inferior to understandings gained through fieldwork.

My personal connection to the Everglades landscape, and the national park, has granted me great sympathy to these early naturalists' concerns and sense of despair. ${ }^{79}$ But the costs of this generification have been high and disproportionately meted out. Though it took several decades, the national park's establishment in 1947 led to the forced removal of families who had lived at the fishing settlement of Flamingo for nearly 100 years and the eradication of commercial farming on lands adjacent to Royal Palm. The subsequent destruction of Flamingo's village site was particularly painful to locals. Although locals continued to hunt in the park for several decades, these activities were treated as criminal, mirroring their pre-park constructions, and hunters' lives were marked by a poetics of avoiding detection, underground economies, and disciplinary action. Traditional subsistence and commercial practices became 'emparked,' a mode of power Joe Hermer has argued characterizes the legislatively-defined stewardship of North American parks and protected areas. ${ }^{80}$

This generification was also instrumental to contemporary narratives of the landscape. The visitor's experience of Royal Palm is of a landscape curiously devoid of human history. 
The countless interpretive materials at the site make no mention of the various peoples who once considered this hammock home or depended upon the hammock for their livelihoods. Other locations in the park do provide some historical interpretation, though these are the familiar stories of human-induced ecological disaster: plume hunters and the near-extinction of glorious wading birds, drainage schemes and habitat loss, the threat of introduced species to native biota.

My intention here is not to demonstrate that the Everglades is also a place of people, though this is an important point. Instead, I explore the ways in which the knowledge regime that creates the Everglades as an ecological landscape is bound in the landscape's social nature. In doing so, I hope to frame the ecological history of the region in what Jasanoff has called a 'coproductionist' idiom, which specifically underscores social and material dimensions of scientific knowledge production. ${ }^{81}$ As I demonstrate here, the material means by which Royal Palm became ecologically significant was contingent upon the embodied knowledge of local people who both appreciated the landscape and acted as agents of transforming the landscape. My hope is that this article serves as a reminder that the Everglades, as a landscape of ecological significance, becomes such not only through the work of men and women granted the authority to speak for nature, but also through the collaborations of those who considered the Everglades home.

\section{Biographical note}

Laura A. Ogden is Assistant Professor of Anthropology at Florida International University. She has published several articles on the politics of Everglades restoration science. Currently she is writing The Bill Ashley Jungles: landscape ethnography in the Florida Everglades, a book that maps the entanglements of nature, community history, stories of girl gangs, among other things, in the spatial practices of Everglades alligator hunters. She can be contacted at: Department of Sociology/Anthropology, Florida International University, Miami, Florida, 33199, USA; email: OgdenL@fiu.edu

\section{Notes}

1 I would like to acknowledge the assistance of several people who helped with this article. Foremost, I would like to thank the glades community, particularly Glen Simmons, who have patiently answered my questions and taught me what I know about the Everglades. Gail Hollander provided invaluable and insightful comments on various drafts. She helped to both strengthen the article's direction and writing. Three anonymous reviewers for Cultural geographies were equally important to the process, their rigorous engagement and suggestions for additional literature provided critical focus to my argument. This article began, countless revisions ago, as a chapter for my dissertation. I would like to thank Tony Oliver-Smith, my chair and friend, for his mentorship then and now. Last, the research for this article was supported through the Environmental Protection Agency's Science to Achieve Results dissertation fellowship.

2 N. Myers, 'Threatened biotas: "hot spots" in tropical forests', Environmentalist 8 (1988), pp. 187-208.

3 A. Leopold, A Sand County almanac and sketches here and there (New York, Oxford University Press, 1949).

4 T.E. Lodge, The Everglades handbook: understanding the ecosystem (Delray Beach, FL, St. Lucie Press, 1994); J.A. Simpson and E.S.C. Weiner, eds, Oxford english dictionary on CD-ROM (2nd Edition) (Oxford, Clarendon Press, 1989). 
5 R.H. Humes offers a fascinating account of Liguus tree snail collecting in the Everglades. See R.H. Humes, 'A short history of Liguus collecting: with a list of collectors - 1744 to 1958', Tequesta 25 (1965), pp. 69-74.

6 W.S. Jennings, Mrs, 'Royal Palm State Park', Tropic magazine 4 (1916), pp. 10-26. The Florida Federation of Women's Clubs successfully led the effort to establish the Royal Palm Hammock as a state park in 1916. In her account of the park's establishment, May Mann Jennings, the wife of Florida's Governor, offers great insight into both the way in which women used their social and political connections to influence the environmental politics of the era, and the bureaucratic and legal difficulties of establishing claims over largely unmapped landscapes. In this history of the park's establishment, she specifically cites the work of John K. Small and Charles T. Simpson as evidence of the hammock's ecological worth.

7 P. Crang, 'Introduction: field cultures', Cultural geographies 10 (2003), p. 251.

8 See C. Tilley, 'Introduction: landscape, place, landscape and heritage', Journal of material culture 11 (2006), pp. 7-32, for a recent overview of the landscape literature. See also, K. Basso, 'Wisdom sits in places: notes on a Western Apache landscape', in S. Feld and K.H. Basso, eds, Senses of place (Santa Fe, NM, School of American Research Press, 1996); B. Bender, 'Subverting the western gaze: mapping alternative worlds', in P. Ucko and R. Layton, eds, The archaeology and anthropology of landscape: shaping your landscape (London, Routledge, 1999); B. Bender, 'Time and landscape', Current anthropology 43 (2002), pp. S103-12; T. Cresswell, 'Bourdieu's geographies: in memoriam', Environment and planning d: society and space 20 (2002), pp. 379-82; T. Cresswell, 'Landscape and the obliteration of practice', in K. Anderson et al., eds, Handbook of cultural geography (London, Sage, 2003), pp. 269-81; M. Dorrian and G. Rose, 'Introduction', in M. Dorrian and G. Rose, eds, Deterritorialisations ... revisioning landscapes and politics (London, Black Dog Publishing Limited, 2003); D. Matless, 'Introduction: the properties of landscape', in K. Anderson et al., eds, Handbook of cultural geography (London, Sage, 2003); W.J.T. Mitchell, 'Preface to the second edition of Landscape and powver: space, place and landscape', in W.J.T. Mitchell, ed., Landscape and power (2nd Edition) (Chicago, University of Chicago Press, 2002); F. Myers, Pintupi County, Pintupi self: sentiment, place, and politics among Western Desert Aborigines (Washington, DC, Smithsonian Institution Press, 1986); K.C. Stewart, 'An occupied place', in S. Feld and K.H. Basso, eds, Senses of place (Santa Fe, NM, School of American Research Press, 1996); M. Taussig, 'The beach (a fantasy)', in W.J.T. Mitchell, ed., Landscape and power (2nd Edition) (Chicago, University of Chicago Press, 2002); C. Tilley, A phenomenology of landscape: places, paths and monuments (Oxford, Berg, 1995); P. Walker and L. Fortmann, 'Whose landscape? A political ecology of the "exurban" Sierra', Cultural geographies 10 (2003), pp. 469-91.

9 J. Fairhead and M. Leach, Misreading the African landscape: society and ecology in a forest savanna mosiac (Cambridge, Cambridge University Press, 1996); K.I. MacDonald, 'Global hunting grounds: power, scale and ecology in the negotiation of conservation', Cultural geographies 12 (2005), pp. 259-91; R. Neumann, 'Ways of seeing Africa: colonial recasting of African society and landscape in Serengeti National Park', Ecumene 2 (1995), pp. 149-69; R. Neumann, Imposing wilderness: struggles over livelihood and nature preservation in Africa (Berkeley, University of California Press, 1998); R. Neumann, 'Nature-State-Territory: toward a critical theorization of conservation enclosures', in R. Peet and M. Watts, eds, Liberation ecologies (2nd Edition) (London, Routledge, 2004), pp. 195-217; D. Rossiter, 'The nature of protest: constructing the spaces of British Columbia's rainforests', Cultural geographies 11 (2004), pp. 139-64.

10 T. Cresswell 'Theorizing place', in T.J. Cresswell and G. Vertstraete, eds, Mobilizing place, placing mobility: the politics of representation in a globalized world (Amsterdam, Rodopi, 2003), pp. 11-32; J.J. Fox, The poetic power of place: comparative perspectives on Austronesian ideas of locality (Canaberra, Department of Anthropology with the Comparative Austronesian Project Research School of Pacific and Asian Studies, Australian National University, 1997); A. Mills, 'Boundaries of the nation in the space of the urban: landscape and social memory in Istanbul', Cultural geographies 13 (2006), pp. 367-94; 
D. Trudeau, 'Politics of belonging in the construction of landscapes: place-making, boundary-drawing and exclusion', Cultural geographies 13 (2006), pp.421-43; D.S. Moore, 'Subaltern struggles and the politics of place: remapping resistance in Zimbabwe's Eastern Highlands', Cultural anthropology 13 (1998), pp. 344-81; D.S. Moore, Suffering for territory: race, place, and power in Zimbabwe (Durham, NC, Duke University Press, 2005); E. Said, 'Invention, memory and place', in W.J.T. Mitchell, ed., Landscape and power (2nd Edition) (Chicago, University of Chicago Press, 2002); T. Selwyn, 'Landscapes of liberation and imprisonment: towards an anthropology of the Israeli landscape', in E. Hirsch and M. O'Hanlon, eds, The anthropology of landscape: perspectives of place and space (Oxford, Claredon Press, 1995).

11 S. Jasanoff, 'The idiom of co-production', in Sheila Jasanoff, ed., States of knowledge: the co-production of science and social order (London, Routledge, 2004), p. 3.

12 See Jennings, 'Royal Palm State Park'.

13 For an excellent overview of the literature, particularly within Anthropology, see P. West, J. Igoe and D. Brockington, 'Parks and peoples: the social impacts of protected areas', Annual review of anthropology 35 (2006), pp. 25-277; K. Jacoby, Crimes against nature: squatters, poachers, thieves, and the bidden history of American conservation (Berkeley, University of California Press, 2001).

14 An unnamed soldier provided a graphic account of the raid in Notes on the passages across the Everglades', St. Augustine Weekly News, 8 January 1848. A typed copy of this article can be found in John M. Goggin Papers, Special and Area Studies Collections, George A. Smathers Libraries, University of Florida, Gainesville, Florida.

15 J.C. Taylor, Introduction to 'Railway location in the Florida Everglades', by William J. Krome, Tequesta 39 (1979), pp. 5-7.

16 G. Simmons and L. Ogden, Gladesmen: gator bunters, moonshiners, and skiffers (Gainesville, University of Florida Pres, 1989); L. Ogden, 'Gladesmen of the Florida Everglades: a landscape poetics', dissertation (Gainesville, University of Florida, 2002); L. Ogden, 'The Bill Ashley Jungles: landscape ethnography in the Florida Everglades', in preparation.

17 Braun, The intemperate rainforest, pp. 26-57.

18 J. Clifford, The predicament of culture: twentieth-century ethnography, literature, and art (Cambridge, Harvard University Press, 1988), pp. 215-51; C.M. Hinsley, Savages and scientists: the Smithsonian Institute and the development of American anthropology 1846-1910 (Washington, DC, Smithsonian Institute Press, 1981).

19 B. Latour, Politics of nature: how to bring the sciences into democracy (Cambridge, Harvard University Press, 2004), p. 22.

20 In West, Igoe and Brockington, Parks and peoples, p. 261, the authors describe generification as a representational tactic whereby people (and their relationships to landscapes) are made to fit into pre-existing categories (poacher, native, etc.), thereby making these peoples and places less complicated to outsiders; see also P. West and J.G. Carrier, 'Getting away from it all? Ecotourism and authenticity', Current anthropology 45 (2004), pp. 483-98.

21 R. Kohler, All creatures: naturalists, collectors, and biodiversity, 1850-1950 (Princeton, NJ, Princeton University Press, 2006).

22 Daniel B. Beard, who became the first superintendent of Everglades National Park, conducted a survey of the proposed park in 1938. In his report, Wildlife reconnaissance: Everglades National Park project (Washington, DC, National Park Service, 1938), Beard quotes Clifford C. Presnell, at the time the Assistant Chief of the Wildlife Division for the National Park Service. Presnell's experience of the Everglades captures the sense of dislocation outsiders felt in this landscape, of the Everglades he wrote ${ }^{\circ}$ They are mystical and strange, having a peculiar enveloping atmosphere of timelessness that is most poignantly felt when one traverses the dark mazes in a boat. Under such condition there is a feeling of vague uneasiness, even of slight depression, a sense that this will always be a wilderness capable of overwhelming the puny efforts of mankind by the sheer exuberance of its own life' (p. 2). 
23 H.L. Willoughby, Across the Everglades: a canoe journey of exploration (reprint) (Port Salerno, FL, Florida Classics Library, 1992 [1898]). 1915), p. 217. fieldwork in South Florida, see L. La Plante, 'The Sage of Biscayne Bay', pp. 61-83.

41 C.T. Simpson, 'Paradise Key', Tropic magarine 4 (1916), pp. 5-9. T. Barbour, That vanishing eden: a naturalist's Florida (Boston, Little, Brown and Company, 1944), p. 162. F.M.Chapman 'Everglade Islet', Audubon magazine 45 (1943), pp. 19-25.

A.H. Howell, 'A list of the birds of Royal Palm Hammock, Florida', Auk 38 (1921), p. 251.

E.O. Rothra, Florida's pioneer naturalist: the life of Charles Torrey Simpson (Gainesville, University Press of Florida, 1995), p. 85. Small, 'Royal Palm Hammock', p. 168.

Simpson, In lower Florida wilds, pp. 130-3. See also Rothra, Florida's pioneer naturalist, pp. 84-5.

Simpson, In lower Florida wilds, pp. 130-3.

For information on P.H. Rolfs, see his memorial [J.R. Watson], 'Dr. Peter Henry Rolfs', Florida entomologist, 27 (1944), pp. 1-5.

See E.O. Rothra, 'John Clayton Gifford: 1879-1949', in J. Gifford, On preserving tropical Florida, compiled by Rothra (Coral Gables, FL, University of Miami Press, 1972), for biography of Gifford.

Safford, Natural history of Paradise Key and the nearby Everglades of Florida, p. 377.

A.H. Howell, Florida bird life (Coward-McCann, New York, 1932); Howell, 'A list of the birds', p. 252.

J.K. Small, 'Exploration in Southern Florida', p. 38. See also J.K. Small, 'Coastwise dunes and lagoons: a record of Botanical exploration in Florida in the Spring of 1918', Journal of the New York botanical garden 20 (1919), pp. 191-207, for Small's account of the discovery of a heliotrope relative at the site. Publishers, 1996), p. 143. 
53 Safford, Natural bistory of Paradise Key, p. 377.

54 M.L. Pratt, Imperial eyes: travel writing and transculturation (London, Routledge, 1992) for an insightful discussion of the articulations of natural history as a discipline, the work of Alexander von Humboldt, Romanticism, and the construction of tropical nature.

55 Kohler, All creatures, p. 157.

56 Kohler, All creatures, pp. 18, 157-61, 160.

57 The naturalist Francis Harper, who worked in the swamps of southern Georgia beginning in 1912, provides a vivid portrait of the lives of 'swampers' during this time period, in F. Harper and D.E. Presley, Okefinokee album (Athens, GA, University of Georgia Press, 1981).

See H.A. Kersey, Jr, Pelts, plumes, and bides: white traders among the Seminole Indians, 1870-1930 (Gainesville, FL, University Presses of Florida, 1975) for a history of the hide trade in Florida documenting interaction between white and Seminole hunters; see G. Simmons and L. Ogden, Gladesmen: alligator hunters, moonshiners, and skiffers (Gainesville, FL, University Presses of Florida, 1998) for additional history of the Everglades hide trade.

59 G. Simmons and L. Ogden, Gladesmen, p. 35.

${ }^{60}$ Beard, Wildlife reconnaissance, pp. 84-5, discusses hunting in the pre-park area during the late 1930s.

${ }^{61}$ Small, 'Royal Palm Hammock', p. 1.

62 Office of the Publishers' Weekly, The annual American (New York, NY, R. R. Bowker, 1898), p. 215; F.F. Brown and W.R. Brown, eds, The dial: a semi-monthly journal of literary criticism, discussion and information 24 (1898), pp. 186-8; State library bulletin, volume 1, (Albany, NY, University of the State of New York, 1899), p. 592.

${ }^{63}$ J.K. Small, 'Exploration in southern Florida in 1915', Journal of the New York botanical garden 17 (1916), p. 37.

${ }^{64}$ Simpson, Out of doors, p. 137; see also Simpson, In lower Florida wilds, p. 141.

65 Small, 'Royal Palm Hammock', p. 170; Small, 'Exploration in southern Florida', p. 41.

66. Miami metropolis 1896.

67 Small, 'Royal Palm Hammock', p. 167.

68 Simpson, Out of doors, p. 381.

${ }^{69}$ Kohler, All creatures, p. 18.

70 P. George, 'Brokers, binders, and builders: greater Miami's boom of the mid-1920s', Florida historical quarterly 65 (1986), p. 35.

71 George, 'Brokers, binders, and builders', p. 30.

72 Jacoby, Crimes against nature.

73 Jennings, 'Royal Palm State Park', p. 10.

74 Miami metropolis 1896; see also Simpson, Out of doors, p. 243.

75 Jennings, 'Royal Palm State Park'.

76 Simpson, 'Paradise Key', pp. 6-7; see also Small, 'Royal Palm Hammock', p. 9.

77 Simpson, 'Paradise Key', pp. 6-7.

78 Latour, Politics of nature, p. 22.

79 At different times in their careers, both of my parents worked for Everglades National Park where they conducted field surveys and other natural science research projects, including investigations within Royal Palm. In fact, I was brought home as a newborn to live in a cramped trailer in the park's housing compound, not far from the hammock itself.

80 J. Hermer, Regulating eden: the nature of order in North American parks (Toronto, University of Toronto Press, 2002), pp. 114-5.

81 Jasanoff, 'The idiom of co-production', p. 3. 